\title{
Re-Examine Conventional Concepts in Urban Design: The Conflict Between Urban Space Utilization and the Elements of Power and Control - Case of Hawkers within Amman, Jordan
}

\author{
Dania Abdel-Aziz ${ }^{* *}$ \\ 1 The University of Jordan, Dept. of Architecture, Amman, Jordan \\ * archdania.aziz@gmail.com
}

Accepted: 01.06.2021

\begin{abstract}
Architecture and urbanism are disciplines based on knowledge of space. From this point of view, this research aims to study the challenges of dealing with hawkers (Street Vendors) in Jordan's urban centres generally by shedding light on downtown Amman. Although they succeed in acquiring and controlling space informally in Amman, hawkers have been ignored by local planners and even been harassed by local authorities for not being given space to operate their businesses. Rigid transformations should be carried in urban planning strategies in downtown Amman. Local policies need to be enforced to end this conflict and provide suitable conditions and capacities to read and respond to the hawkers' needs. They represent an integral part of the region's urban fabric. This study is based on reviewing related literature, field survey, and observations carried out for two months in the study area. In addition to several informal discussions held with the hawkers, pedestrians, merchants, and local authorities, questionnaires were used to clarify specific issues. The study suggests a few recommendations to help fulfil urban centres' effective utilization and harmonize formal activities and the hawkers in order to resolve this conflict. The study found that street hawkers are only considered troublemakers and have never been involved in decision-making when urban planning occurs. These will be an ongoing issue, not unless they are integrated into the planning processes. The study suggests different scenarios for proper allocation of hawking space can be done regarding accommodating them according to their space requirements worked out the basis of the products sold, as has been done in the present study. In short, this will help in providing suitable trading environments for the hawkers, creating a pedestrianfriendly neighbourhood, decreasing the unemployment rate, among other advantages.
\end{abstract}

Keywords: Street vendors; central business district; convivial urban space; national policy; hawking space

\section{Introduction}

With the continually increasing population due to the crises in its neighbouring countries (Nilsson\& Borges, 2019) and pressure on jobs, Jordan is witnessing a noticeable increase in unemployment, especially among youth. The government is now unable to provide suitable job opportunities for their citizen; that's why many Jordanians were forced to work in the 
informal sector to escape worsening unemployment in the country, especially as many support their families. Despite the limited income and the high cost of living, they face daily pursuit by the local authorities who seize their goods; they are forced to pay fines or give up what was confiscated from them, making their situation worse.

Jordan's unemployment rate has been alarming and has increased from $11 \%$ in 2010 to $19 \%$ by 2019 (DoS, 2020). The participation rate of Jordan's workforce has remained one of the lowest in the world at about 40\% (Husseini, 2016). The youth unemployment rate in 2018 was very high, about 37.2\%, and among the highest globally (The World Bank, 2019). The unemployment rates have traditionally been higher in rural areas than in urban areas due to the concentration of jobs in urban governorates and the lack of transportation or reluctance to use it (Husseini, 2016). This made many people move from rural areas running from poverty to urban areas (rural-urban migration). But those migrants do not possess the skills or education to find suitable paid and secure employment in the formal sector. This made them settle for work in the informal sector. Sharma (2016) discussed another reason why people are pushed to work in the informal sector. According to her, many businesses, factories and workshops were closed, and the previous workers could not find a proper job; hence they had to work in the informal sector to survive.

The meaning of the informal sector has been discussed by many researchers (Schneider, 1986), (Smith, 1994), (Saunders \& Loots, 2015), (Dhakal, 2015) and others. The informal sector, as Smith (1994) defines it is a market-based production of goods and services, whether legal or illegal, that escapes detection in the official estimates of GDP. According to the International Labor Office (ILO) definition, the informal sector is: "The informal economy is broadly characterized as consisting of units engaged in the production of goods and services with the primary objective of generating employment and income to the persons concerned." (ILO, 1993:2). The activities in the informal sector can be categorized into two sections; (1) the selfemployed and (2) the non-permanent labour (Sharma, 2016). Self-employment is one of the modern development concepts that switched perspectives in business and employment, which means the individual's quest to find a job for themselves through the reliance on their ideas, experiences, and educational and training level. A significant section of the selfemployed workers are hawkers or street vendors. The rise in the number of street hawkers is due to the lack of employment in other sectors and directly linked to the informal sector's expansion.

The term "Hawkers" is an interchangeable phrase that refers to people who tends to sell goods or offer services to the public informally in any street or public place. These activities are not being protected or supervised by the government; that's why they do not have a fixed place or a permanent built-up structure. Hawkers tend to spread or display goods in open spaces or temporary static structures to attract buyers and make sales. It also refers to the person who moves from one place to another or goes to people's homes to sell goods or merchandise that he offers for sale or deals in his craft or industry by roaming (GAM, 2009). The hawker may use a trolley, kiosk, canopy, or merely using the pavement, see Figure 1. 


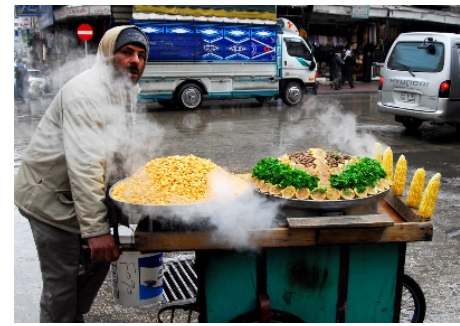

a

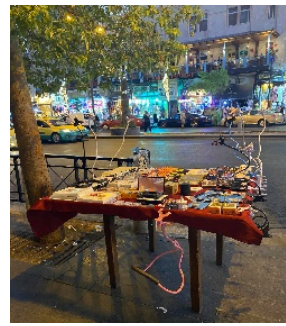

$\mathrm{b}$

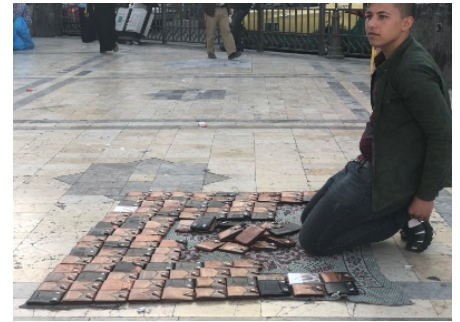

$C$

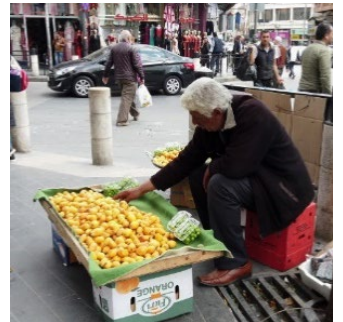

d

Figure 1. Various means used by the hawkers at the study area (Amman downtown) to present their goods and services. a) trolley, b) table, c) rug, d) boxes

Modernist planning focuses on cars' requirements rather than pedestrians' needs and expectations, making cities lose many qualities (Israt, 2019). Good accessibility is directly related to the pedestrians' thoughts and experience. It acts as a direction for the pedestrians that, as a result, affect their perception. We cannot neglect the fact that there are many problems associated with mobility and accessibility resulting from hawking in Amman downtown's streets. Simultaneously, if planners, when planning to pedestrians, took hawkers into account, many problems could be avoided. An external view of hawking in Jordan gives the impression of this sector's randomness regarding distribution and spread. In reality, it is a sector with a remarkable degree of control, and over time it had its traditions and inner life. Families are working in hawking for three generations, and there is a great deal of specialization in the sector.

The Greater Amman Municipality's (GAM) Campaigns against the phenomenon of street vending began in 1997. Some of these campaigns were very severed and targeted local markets as well (Khalil, 2019). Hawkers tended to move between many locations, while some chose to work during the night or early morning. At the same time, GAM did not provide alternative markets. GAM, as a regulatory body, is working to violate this sector because of the quality of goods that are handled since they are usually poor and not suitable for consumption. Moreover, since these workers have a specific place or are evading paying taxes and fees, it leads to a breach of security and order, the use of sidewalks, and obstructing citizens' movement. Another justification for GAM's campaigns can be in the urban landscape. But this contradicts reality, as these hawkers, especially in Amman downtown, constitute a cultural and heritage character and reflect a real image of the people. That's why these campaigns to date do not have the capabilities to withstand and continue. The GAM should see the informal sector's other sides and be aware of the critical role that the urban informal sector plays in the urban economy worldwide. An organized street vending in Amman or other urban space in Jordan could be part of city precedence for the city community's benefit.

\section{Problem Statement}

With high unemployment rates, increasing poverty, and the high cost of living in Jordan, hawkers' flow into urban centres has become a distinguishing feature of most cities. Still, they are often regarded as an 'element out of place' (Widjajanti, 2016). Their problem is the absence of reference in determining their activity's location in the city plan. Their random distribution causes many problems. For a sustainable community for its inhabitants, it must be liveable. To achieve suitable and orderly urban intervention; policy guidelines concerned with the effective use of urban centres must be formulated, customized and developed to address urban space users. In downtown Amman for example, most urban spaces are conquered by hawkers. Hawkers' rugs are spread over a wide range of different forms (see Figure 2.), on the sidewalk 
inside the bazaars and local markets, in front of the Grand Husseini Mosque, see Figure 1. GAM has always fought against the hawkers. But at the same time, it did not try to understand their needs, did not provide them with job opportunities that would spare them all these conflicts. The government must provide solutions to overcome this crisis and help people. Hence the importance of recognizing them, laying down laws that regulate their work and their whereabouts in a way that achieves balance and the public interest. Sustainable planning should address spatial integration issues and resolve conflicts and hawkers' movement within the urban fabric. The purpose of this study is to examine the spatial processes and requirements in the areas where street hawkers are present. Urging the authority to propose suitable sites for hawkers, relocate them within urban spaces, plan their activities, and direct their growth and development in an organized pattern. The study assumes that the population of hawkers will continue to increase in Amman downtown. This means extra urban space is required to conduct their activities. The GAM has to restore economic growth, generate employment opportunities to absorb the unemployed's large numbers, particularly the youth, and reduce poverty levels.
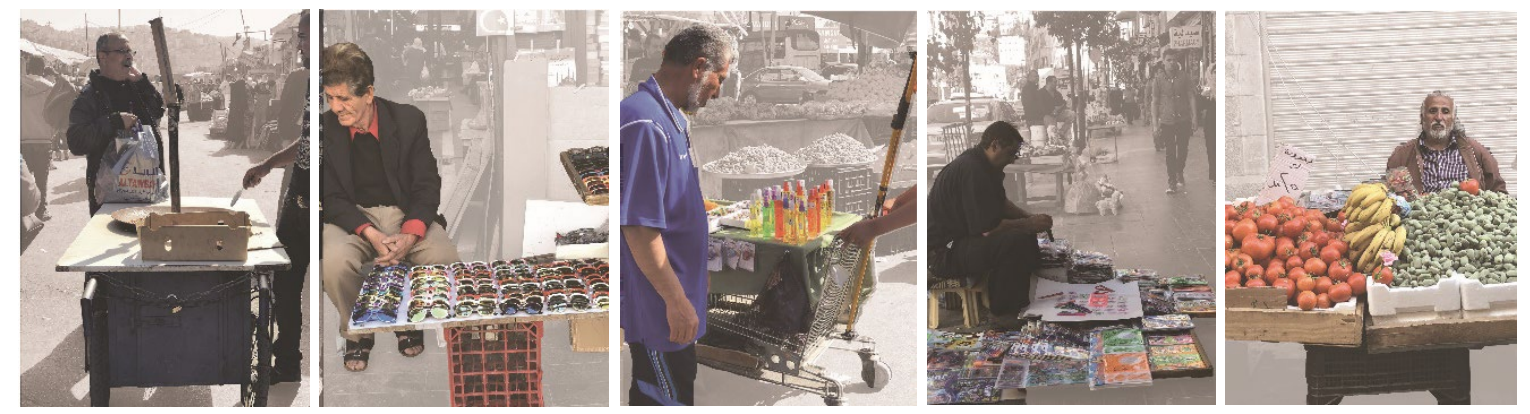

Figure 2. Different hawkers' units spread in Amman Downtown within the study area

\subsection{Objectives}

Public spaces are open for all to use and raise the difficulties in balancing pedestrians' right to move freely in the city and the hawkers to work legally and earn money to live a better life. The research will try to solve this conflict and fill the gap and build a sustainable city community. By suggesting scenarios where hawkers can be relocated in desirable urban spaces within the urban structure, they can conduct their business, considering accessibility, comfort, and characteristics referring to their activity. From this point, the research aims to provide quantitative norms, theories and concepts for accommodating street hawkers legally in Amman downtown. See Figure 3. 


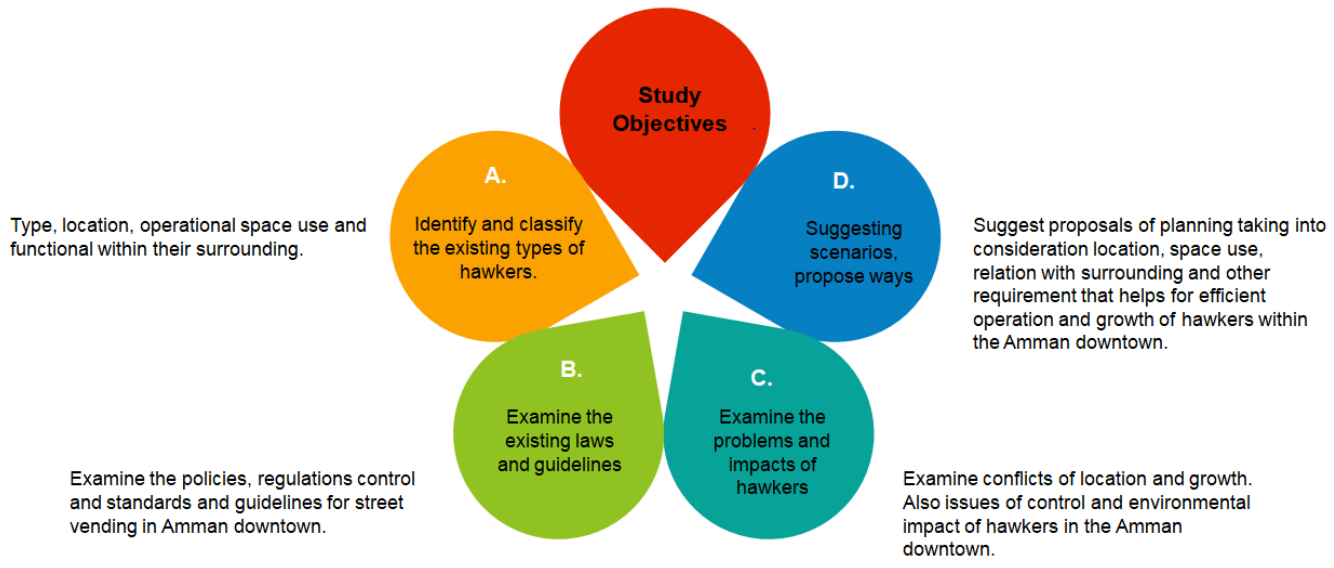

Figure 3. Study objectives

\subsection{Methodology}

This study is based on quantitative and qualitative methods; Figure 4 summarizes the data collection sources. This study is centred on (1) reviewing related literature; searching the concept of the informal sector, conflicts between hawkers, merchants, pedestrians and government, (2) field survey and of hawking establishments in the Amman downtown, the type of the goods, the size of the unit, etc., walking within the study area and observing pedestrian movement, the road network, how the hawkers related to the urban space and taking photographs of the activities (3) informal discussions with hawkers to collect information about the related problems and difficulties they face, the nature of their work, their needs, nature of their business, characteristics of their specific activity, their dependence on the site context, (4) questionnaires were carried out for formal business operators, pedestrians and study area visitors (5) Analysis of primary and secondary information and (6) conclusion and recommendations. The field survey was carried out after preliminary studies were made from related literature. The analysis of all collected data was presented using analytical tables. While the questionnaires were analyzed using Statistical Package for Social Science (SPSS).

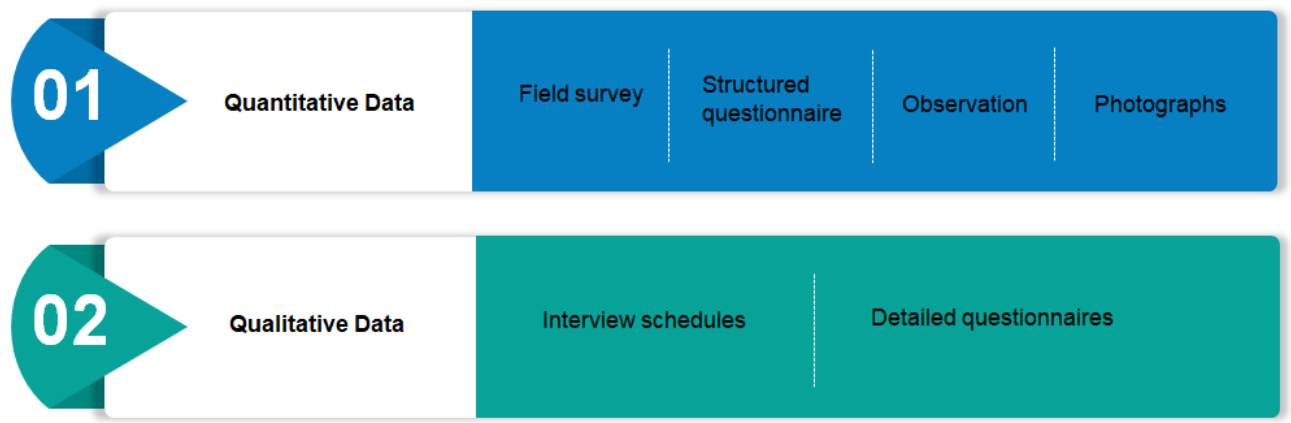

Figure 4. Data collection methods

\section{Study Area}

Amman is the capital of Jordan, and it covers $1680 \mathrm{~km}^{2}$ of land area. $38 \%$ of Jordan's population live there; hence it is considered the most densely populated region (Potter et al., 2009). Lack of adequate housing, unemployment, poor air quality, transportation, water shortages, rapid population growth, hawking or street vending in urban centres is among the most common 
problems of Amman's urbanization. These challenges are putting Amman in a massive problem in terms of its sustainability. The detailed study area in Amman downtown was defined by the area enclosed by King Faisal Square, Als-Saadeh Street, Ar-Reda Street, and the illustrated parts of King Talal Street and Shaaban Street; as shown in Figure 5 below. In the selected study area, the observation subjects were (1) spaces the hawkers were occupying and (2) the specific business venture in which the hawkers were engaged. For this study, the famous Friday market was excluded.

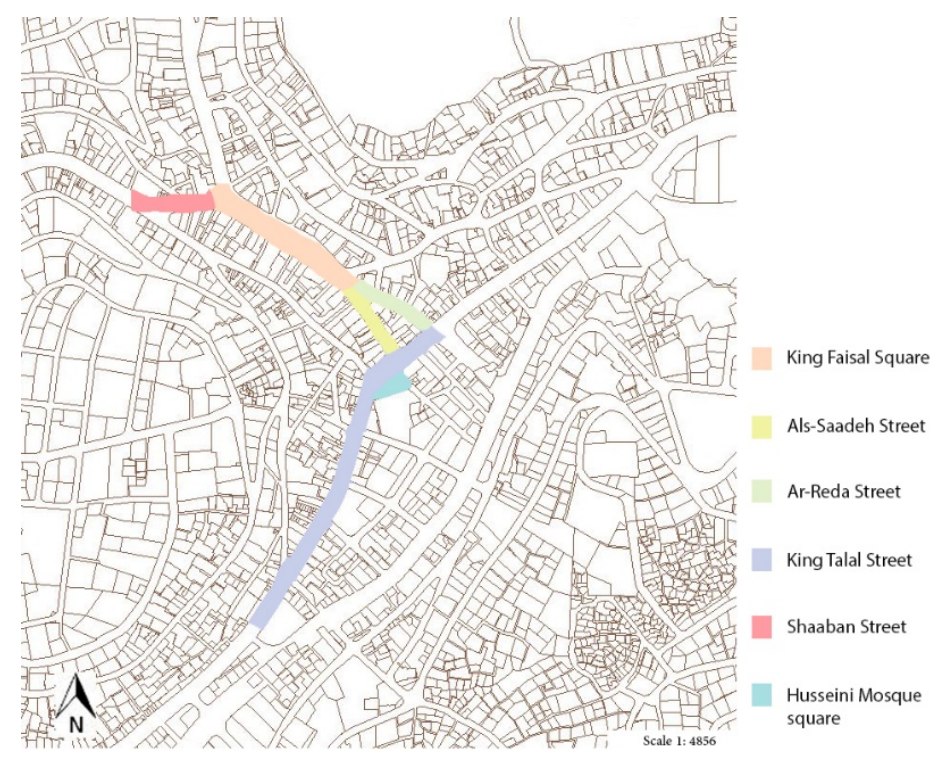

Figure 5. Study area

The target population for this research was; (1) all the hawkers who trade in the alleys of the study area, (2) pedestrians, (3) the merchants or the formal businesses owners in the surrounding area which hawkers located near their businesses and (4) the local authorities and Greater Amman Municipality departments. The activities of hawkers were extensive; this study classified them into three main "relatively" homogeneous categories; (a) food activities (such as; seasonal fruits and vegetables, local sweets, boiled corn and light snacks), see Figure 6., (b) clothing activities (such as; clothes (second hand and new ones), sunglasses, accessories, shoes, belts, watches and bags), see Figure 7. and (c) entertainment activities (such as; accessories, stationery, books, toys, lottery, perfumes, mobile accessories and magic tricks shows and home accessories), see Figure 8. Classifying them was to assess each group's different needs and specifications when relocating is being suggested.
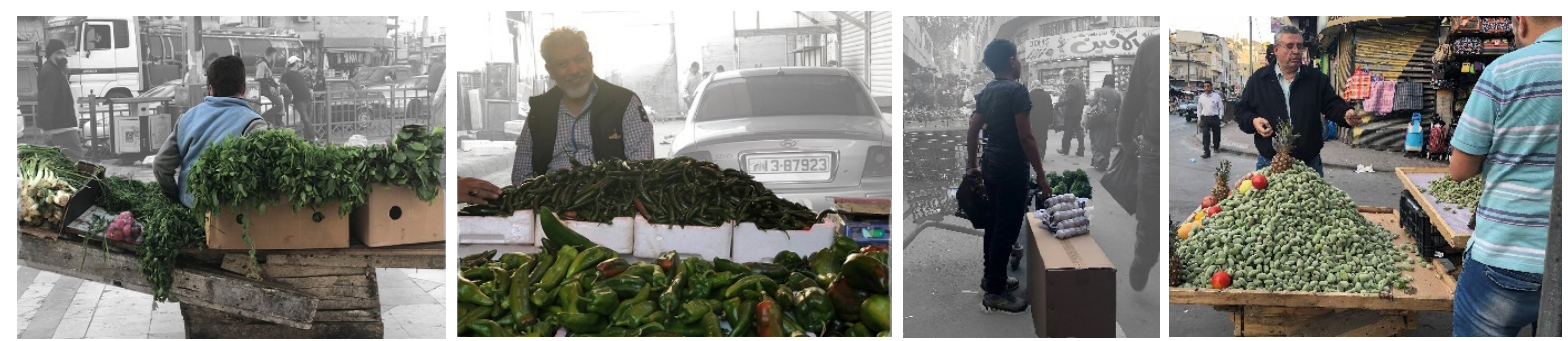

Figure 6. Various hawkers who deals with food activities in the study area 

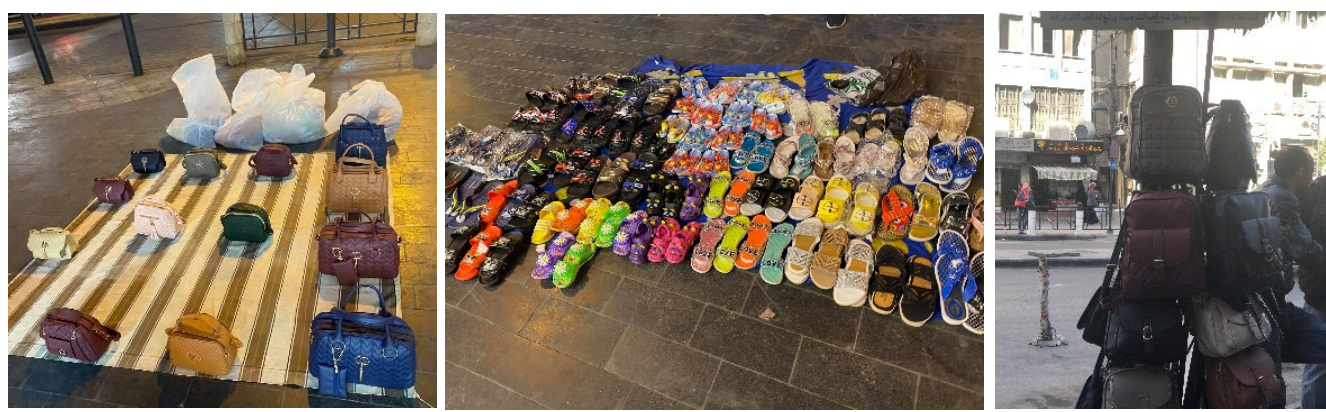

Figure 7. Various hawkers who deals with clothing activities in the study area
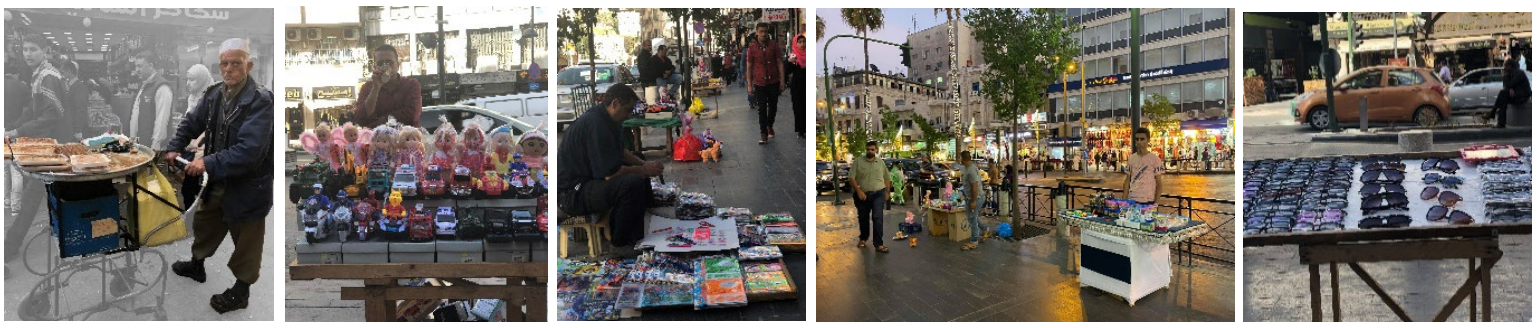

Figure 8. Various hawkers who deals with entertainment activities in the study area

\section{Study Sample}

The fieldwork was carried out between May 2019 and June 2019 in the selected area in Amman downtown. The observed hawkers' units were 168 units; check Tabel 1. The observation was carried out to examine the everyday use, re-use, occupation, and allocation of the urban space and the hawkers' conditions and challenges. It was noted that 152 hawking units were working in the same space uniformly. That's why, for this study, the total sample size is 152 units. The floor space occupied by hawkers is $88.5 \mathrm{~m}^{2}$. For selecting respondents, this study adopted simple random sampling to select hawkers in each category. This technique gave an equal chance to each hawker of being included in the sample.

Table 1. The total number and the occupied space by hawkers in the study area

\begin{tabular}{cc}
\hline Parameter & Unit \\
\hline Total number of hawking units & 168 unit \\
Total sample size & 152 unit \\
Floor space area occupied by hawkers & $88.5 \mathrm{~m}^{2}$ \\
\hline
\end{tabular}

As a representative of the formal sector, a sample size of 12 business owners was selected in the merchants' case. The study aimed to listen to their opinions regarding relocating the hawkers next to their shops/business. While two interviews were held with the GAM staff, and data were collected from 170 respondents to the questionnaire, which was spread through this internet and targeted people who often visit Amman downtown only (respondents must be frequent visitors to the study).

A questionnaire survey was done with hawkers in the study area, most of whom cooperated by answering the questions whilst others refused to answer due to fear. That's why observation was also performed to validate the results and strengthen the findings. This 
survey included structured questions to collect information about the relationship between hawking and public space to build a holistic perception of the current situation in Amman downtown. The questionnaire survey collected data on activities, hawking duration, access, the chosen location, sociability, the informal sector, safety, comfort, uses, faced problems and the user's desires. The data was analyzed using SPSS.

\section{Analysis and Discussion}

\subsection{Site Potentials}

Amman Downtown, which has served as a central commercial area, has many other different land-use activities, which have led to a high frequency of passing for local people and tourists every day. Hawkers assessed this situation as an opportunity to be a selling location and utilize the space for trading activities; Table 2 below summarizes the streets' spatial dimensions and hawkers' percentage in the study area. The accessibility to this area was easy since it is served with public transportations from different locations. Although it is considered a crowded area, the affordable prices of goods and services offered around this area attract consumers. These conditions make this place an attractive area for hawkers to construct their businesses. Moreover, easy access to public transportation relieves the load for hawkers.

Table 2. Spatial dimensions of the streets and hawkers' percentage in the study area

\begin{tabular}{ccc}
\hline Street name & Street length* & $\begin{array}{c}\text { Percentage of } \\
\text { hawkers }\end{array}$ \\
\hline King Faisal Square & $205.90 \mathrm{~m}$ & $50.66 \%$ \\
Ar-Reda Street & $102.50 \mathrm{~m}$ & $8.55 \%$ \\
As-Saadeh Street & $103.30 \mathrm{~m}$ & $9.21 \%$ \\
King Talal Street & $380.50 \mathrm{~m}$ & $30.26 \%$ \\
Shaaban Street & $77 \mathrm{~m}$ & $1.32 \%$
\end{tabular}

* The street's length represents the covered part that the study managed to collect data

\subsection{Strategic Location}

As concluded from the field survey, hawking activities operate in the open, pavement, lanes, and alleys, see Figure 9. The desirable location for hawkers is located within busy pedestrian routes with different activities (shops, hotels, restaurants, etc.) around public transport terminals and bazaars. In other words, the land use activities influenced them to select the space from which they operate. Each day hawkers take their respective positions with their wares ready to sell to potential buyers. They consider that the particular space is attractive for consumers and is located between various activities with a high visitor rate and a high frequency of mobility. 

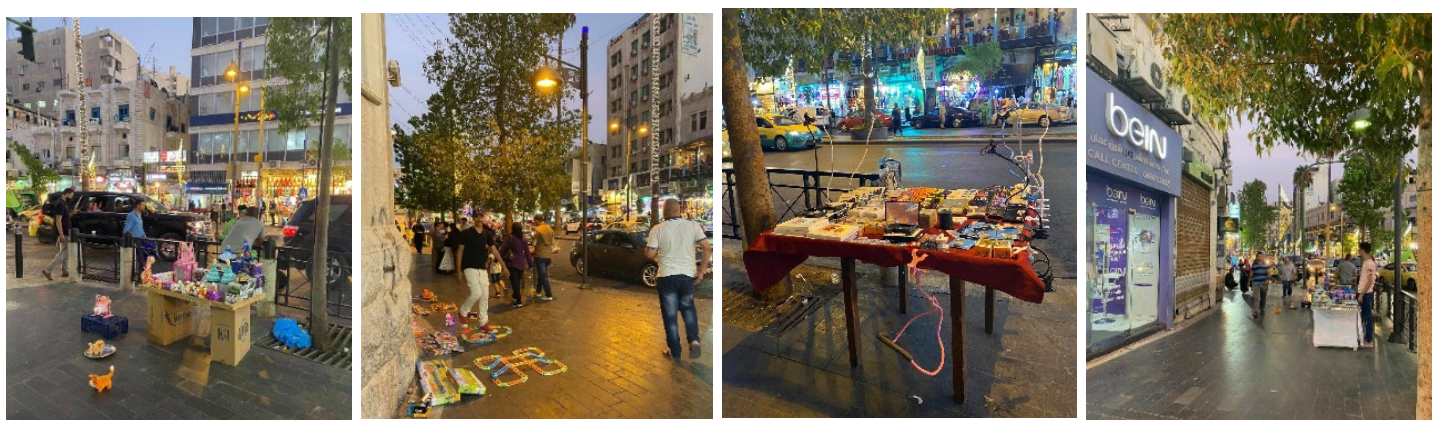

Figure 9. Various pictures show the randomness of hawkers' unit locations within the study area

Every specific space has an owner; as indicated by interviewed hawkers, no other trader would occupy the space without the original space owner's approval. This is a rule that should not be broken. Many hawkers have worked in the same space for more than 40 years, going from generation to generation. Youth hawkers indicated that their fathers were working in the same space before, and now it's their turn to keep working to live. This means that even this informal sector has its own rules. These locations, as hawkers noted, should be safe. In other words, space should be smoothly running away from and easy to be mobile to avoid arrest.

As concluded from the interviews, hawkers transport their goods by two means; 1) on foot. This is done by buying goods from a walking distance market downtown, carrying them on their backs and walking to their trading space, 2) using public transportation to move their goods. From this point, another influence can be seen in selecting its desirable location: public transportation availability. Public transportation facilitates the movement of goods as well as access to the site from their homes.

Some pedestrians complained that some pavements and alleys are just too narrow to accommodate all users and that they cannot move easily. It is recommended that hawkers be removed from streets with such issues to get rid of congestion that obstructs pedestrians' movement.

\subsection{Right in Urban Space}

The hawkers' general problem in their daily operations can be summarized as not being provided with ideal urban space to perform their activities, protecting them from climatic conditions (sun, rain), insecurity, and harassment by the GAM. From the interviews, hawkers pointed out a few critical needs to achieve a convenient place to trade; availability of ample space, ease of modification of goods' means, ease of preparation and presentation of goods, and freedom of movement to serve buyers. They are not governed by the time schedules, such as the formal sector, which gives this sector an advantage of being flexible. Pedestrians agreed that hawkers should have the right to work in the urban space and streets. They also said that they prefer in many times to buy from them because they offer good services within suitable prices compared to shops. On the other hand, many used to buy from them just to help them for living.

As indicated from the survey, the hawkers use trolleys, wooden stands, tables and mats, which they put on the ground to display their goods and services. They tend to use light materials and structures to help them smoothly run away from the GAM. The hawkers who traded in shoes and clothes displayed their goods on light mats to make it easy for customers to pick. The hawking unit's size varies depending on the goods they sell, as indicated in Table 3 below. 
The most common unit size for the food activities category was $1.0^{\star} 1.0 \mathrm{~m}^{2}$ while $2.0^{\star} 2.0 \mathrm{~m}^{2}$ and $2.5^{*} 2.0 \mathrm{~m}^{2}$ for clothing and entertainment activities categories.

Table 3. Space occupied by hawkers within the study area

\begin{tabular}{|c|c|c|c|c|c|c|c|c|c|c|c|c|}
\hline \multirow{2}{*}{ Product type } & \multicolumn{12}{|c|}{ Occupied Space $\left(\mathrm{m}^{2}\right)$} \\
\hline & $1.0^{*} 1.0$ & $1.0^{*} 1.5$ & $1.5^{*} 1.5$ & $1.5 * 2.0$ & $2.0 * 2.0$ & $2.5^{*} 2.0$ & $2.5 * 3.0$ & $2.0 * 3.0$ & $3.0 * 3.0$ & $2.5^{*} 3.5$ & $3.0^{*} 4.0$ & $2.5^{*} 4.0$ \\
\hline Food activities & $28.5 \%$ & & $12.4 \%$ & $16.5 \%$ & & $13.6 \%$ & & $16.5 \%$ & & $18.5 \%$ & & \\
\hline Clothing activities & $15.8 \%$ & $16.5 \%$ & $5.5 \%$ & $11.5 \%$ & $17.3 \%$ & $8.5 \%$ & $6.5 \%$ & $4.5 \%$ & $6.9 \%$ & $3.8 \%$ & & $3.2 \%$ \\
\hline $\begin{array}{l}\text { Entertainment } \\
\text { activities }\end{array}$ & $15.4 \%$ & & $20.3 \%$ & $10.3 \%$ & $17.4 \%$ & $21.5 \%$ & $3.4 \%$ & & $7.5 \%$ & & $2.2 \%$ & $2.0 \%$ \\
\hline
\end{tabular}

\subsection{GAM Act with Regards to Hawking}

The Greater Amman Municipality (GAM) carries out the responsibility of regulating hawking activities in Amman. The primary law is "System for monitoring and organizing hawkers, rugs, umbrellas and kiosks within the boundaries of the municipal areas No. 81 for the year 2009" (GAM, 2009). The provision of this law applies to all municipalities in Jordan except Greater Amman Municipality.

It should be mentioned that in the study area, few hawkers were legally working. When examining these cases, there is a special case or story behind every one of them. One trader has been working for 40 years, having inherited it from his past generation (Family inheritance). The trader specializes in selling Islamic rosaries and other religious products due to its location in the Grand Husseini Mosque plaza. It should be noted that it has been allowed by King Hussein bin Talal. See Figure 10. Another licensed unit is located in King Faisal Street, which a person owns with special needs. This particular trader possesses a license and identification papers that exempt him from paying any fees to the GAM due to his health condition. He noted that it was his only source of income, See Figure 11.

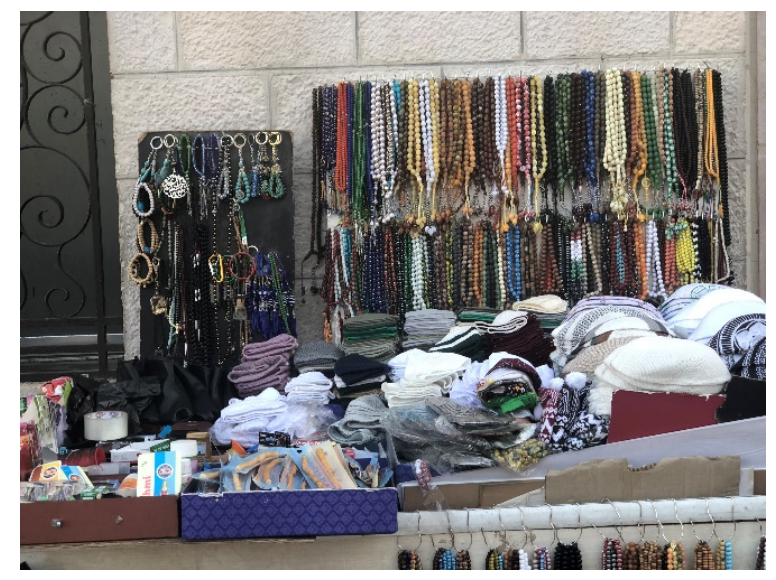

Figure 10. Grand Husseini Mosque case 


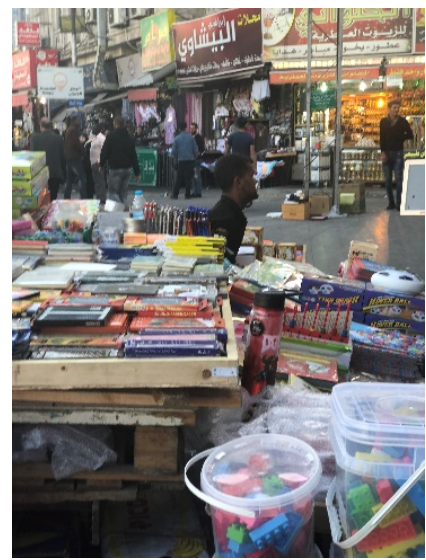

Figure 11. King Faisal Street case

The third one is in King Faisal Street, located at a corner in front of the Gold Market and is dedicated to selling fresh peanuts and has been trading for more than 60 years. This selling unit was distinguished by the fact that tourists were attracted to that particular sight of the owner doing his business. Taking a picture of/with him is no less important to them than taking a picture in the Roman amphitheatre in the same area. Figure 12. Below
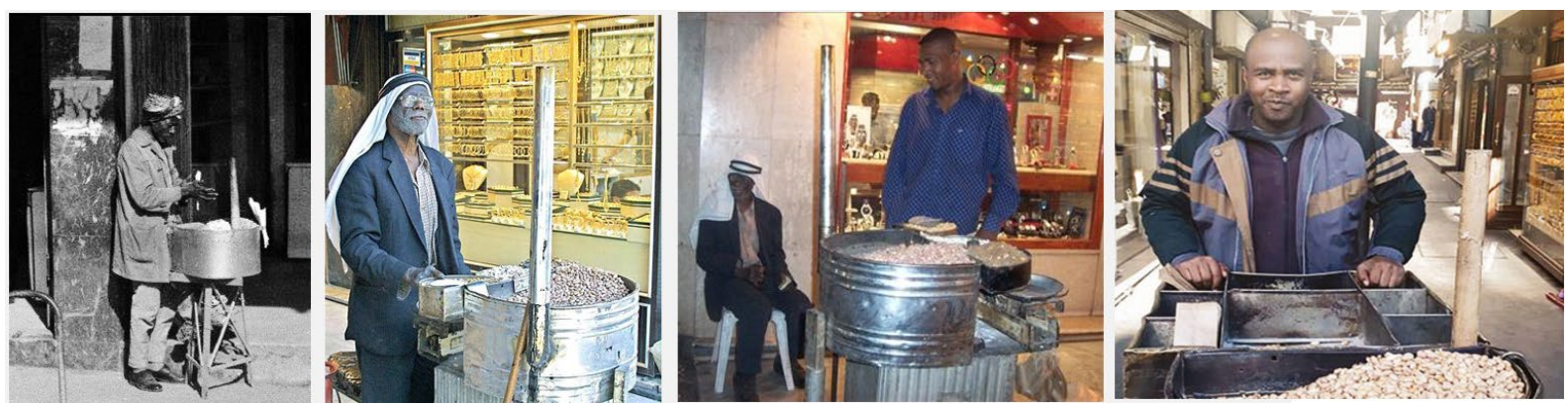

Figure 12. Gold Market case (Alddemh, 2009)

From here, it should be noted that the hawkers in Amman downtown are part of the place's cultural heritage, and they are what attracts tourists to the place. The GAM should help in the economic recovery by supporting hawkers; provide them with permanent trading spaces to overcome the crisis of poverty and the high unemployment rates. This will help achieve improved services by making the urban spaces an attractive place for everyone to live and do business legally without the fear of harassment.

\subsection{Product/Activity Type}

The field study showed many different types of goods hawkers tend to deal with, such as; fruits and vegetables, clothes and bags (second hand and new ones), sunglasses, toys, stationery, lottery, mobile accessories, light snacks. The distribution and percentage of their activities are summarized in Table 4 . The field survey indicates that within the different hawking activities distributed along the study area, clothes and toys $(28.29 \%, 21 \%$, respectively) were the most percentage of the sample size. As mentioned above, this study classified those various types of activities into three categories; check Table 5. Results showed that the maximum concentration of the different categories was located in King Faisal Square. 
Table 4. Distribution of hawking units as per their product type

\begin{tabular}{ccccccc}
\hline $\begin{array}{c}\text { Product } \\
\text { type }\end{array}$ & $\begin{array}{c}\text { King } \\
\text { Faisal } \\
\text { Square }\end{array}$ & $\begin{array}{c}\text { As- } \\
\text { Saadeh } \\
\text { Street }\end{array}$ & $\begin{array}{c}\text { Ar- } \\
\text { Reda } \\
\text { Street }\end{array}$ & $\begin{array}{c}\text { King } \\
\text { Talal } \\
\text { Street }\end{array}$ & $\begin{array}{c}\text { Shaaban } \\
\text { Street }\end{array}$ & $\begin{array}{c}\text { In } \\
\text { Total }\end{array}$ \\
\hline $\begin{array}{c}\text { Toys } \\
\text { Stationary } \\
\& \text { Books }\end{array}$ & $15.07 \%$ & $2.63 \%$ & $1.98 \%$ & - & $1.32 \%$ & $21 \%$ \\
Watches & $0.66 \%$ & - & - & $0.66 \%$ & - & $1.32 \%$ \\
Accessories & $6.58 \%$ & - & $0.66 \%$ & $1.32 \%$ & - & $8.56 \%$ \\
Perfumes & - & - & $0.66 \%$ & $2.63 \%$ & - & $3.29 \%$ \\
Clothes & $8.55 \%$ & $2.63 \%$ & $1.32 \%$ & $15.79 \%$ & - & $28.29 \%$ \\
Mobile acc. & $5.26 \%$ & - & $0.66 \%$ & - & - & $5.92 \%$ \\
Sunglasses & $1.2 \%$ & - & - & $1.97 \%$ & - & $3.17 \%$ \\
Shoes & $2.63 \%$ & $1.32 \%$ & $0.66 \%$ & $0.66 \%$ & - & $5.27 \%$ \\
Bags & $2.63 \%$ & $0.66 \%$ & - & $0.66 \%$ & - & $3.95 \%$ \\
Home stuff & $3.29 \%$ & $1.32 \%$ & - & $3.23 \%$ & - & $7.84 \%$ \\
Food & $3.23 \%$ & & $1.68 \%$ & $1.2 \%$ & - & $6.11 \%$ \\
\hline
\end{tabular}

Table 5. Distribution of hawking units as per their main category

\begin{tabular}{cccccc}
\hline Main category & $\begin{array}{c}\text { King } \\
\text { Faisal } \\
\text { Square }\end{array}$ & $\begin{array}{c}\text { As- } \\
\text { Saadeh } \\
\text { Street }\end{array}$ & $\begin{array}{c}\text { Ar- } \\
\text { Reda } \\
\text { Street }\end{array}$ & $\begin{array}{c}\text { King } \\
\text { Talal } \\
\text { Street }\end{array}$ & $\begin{array}{c}\text { Shaaban } \\
\text { Street }\end{array}$ \\
\hline Food activities & $3.23 \%$ & - & $1.68 \%$ & $1.2 \%$ & - \\
$\begin{array}{c}\text { Clothing activities } \\
\text { Entertainment } \\
\text { activities }\end{array}$ & $21.71 \%$ & $4.61 \%$ & $2.64 \%$ & $21.06 \%$ & - \\
\hline
\end{tabular}

\subsection{The Formal Businesses}

The study showed that most of the formal business sector's problem was that there existed an unfair competition between them and the hawkers, especially if they happen to be selling the same product. However, they have no problem with the presence of hawkers in the area, as long as it does not affect their work. The study also noted that the formal business sector is the suppliers of goods and customers to the hawkers trading in the study area. Some shop owners at the study area used to supply hawkers with products sold at competitive prices or accumulated and wanted to dispose them off and sell them at bargaining prices because there was not enough space in their warehouses.

One of the interviewed hawkers noted that many of them tended to pay a fixed price for the adjacent shop owners to guarantee a specific place for them on the street. While another one said that he has been working for eight years at the same space because the adjacent shop belongs to one of his relatives, he will not pay this amount of money. This is evidence of many points of agreement and points of disagreement between the two parties. 


\subsection{Hawking Units}

The hawking unit's size is essential to be taken into consideration because planners need to ensure that the units are not infringing on the pavements and are not an obstacle to pedestrian movements. The size of a hawking unit varies depending on the specific type of product offered. Standardizing could be problematic in general, but it would be much more efficient in the same category.

The GAM would get revenue in regards to the space occupied. The study recommends that the rates charged by the GAM should reflect the space a hawking unit occupies. This will mean that hawkers pay the GAM for the size of space they need considering that every potential location has a maximum and minimum occupancy area controlling the number of hawkers that can be accommodated in an urban space. Taking into consideration that the desired unit size depends on the spatial needs of each activity, this study suggested space requirements for the hawking unit as follows:

1)Hawking zones should be at the entry/exit points of transport nodes and parking areas. Those zones should be at specific static structures located on pavements and footpaths to assure buses and cars smooth movement.

2)The GAM allowed seven markets in Amman that work during the weekdays. The Friday Market at Ras Alain area was one of them, see Figure 13. It is open every Friday and located in an empty parking area. From here rises the point of spreading this successful case by allowing specific parking areas to accommodate the hawkers during the non-working days.
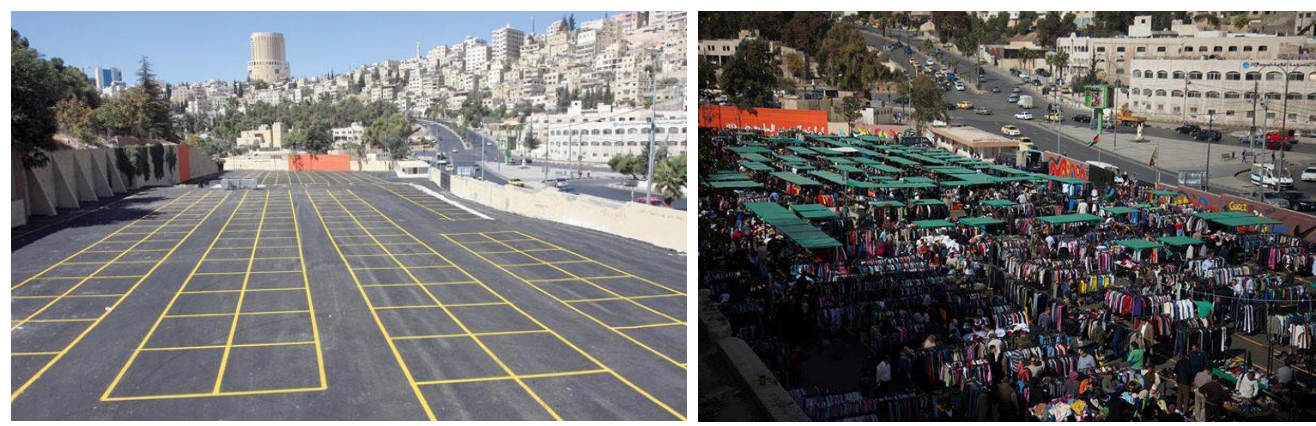

Figure 13. The Friday Market at Ras Al-Ain area; left: designed space, right: space within working hours (Ammonnew, 2014)

3)To avoid clashes with the official shop owners; care must be taken into consideration; (a) maintain a precise distance between the shops and the hawking units, (b) ensure that the hawking units and the shops are not offering the same type of goods and services, (c) maintain sufficient distance for pedestrians to move between the official store and the hawking unit.

4) The width of the pathways should also be taken into consideration. The pathways' minimum width in which it's considered suitable for hawking should not be less than 4 meters. In comparison, units should be separated by a distance of 5 meters minimum to assure pedestrians' free movement and hawkers to work sufficiently.

\section{Conclusions and Recommendations}

Planning should consider the importance of making hawking zones in different streets/cities in Jordan a legal working space because it is believed that an organized street hawking in the urban spaces could be part of city precedence for the city community's benefit. Planners should 
know the need for street hawkers to locate them in certain places may be even at certain times. Those strategic locations should be selected due to accessibility, main activity, demand and space comfort. Indeed, much care should be placed on the street design and ensure a smooth flow for pedestrian movements and the local merchants' interests.

Through participatory planning - while organizing hawkers' activity - planners should ensure all stakeholders' integration to ensure equality, sustainability, and durability of this activity. Hawkers - the urban poor - should be included in formulating and implementing a street roaming activity as part of the stakeholders. Participation will raise awareness about the problem situation, make them more understanding of proposed improvements, and feel more responsible and committed to change. By this, success has a better chance. In short, instead of treating hawkers as an outlaw that only create chaos on the streets, they should be allowed to contribute, Street hawkers can be assets to the development of the urban system. Pedestrian pathways, transport nodes and parking areas have the potential to accommodate hawkers. If adequately located despite the small space, they will find a stable job, a better income and equal dignity as other citizens. By this, hawkers will become a part of the city's socio-economic fabric rather than a problem in this fabric.

Through the development process for Amman's new master plan, the Greater Amman Municipality should provide detailed enforcement procedures for customizing its standards for hawking by specifying the implementing authority. The mechanism and criteria for allocating hawking space and assuring that hawking space allocation should be considered while planning and designing. The hawking space size needs been discussed in this research, but it cannot be generalized to include all the streets or cities in Jordan. Every street and city has a different case scenario. There are some fixed specifications, but it is advised that the space norms for hawking should be included in each zonal development plan for each city alone in Jordan.

\section{Author Statement}

The author confirms sole responsibility for the following: study conception and design, data collection, analysis and interpretation of results, and manuscript preparation.

\section{Conflict of Interest}

The author declares no conflict of interest.

\section{References}

Alddemh, M. (2009). The peanut seller who became one of Amman's landmarks. Online: https: / / archive.aawsat.com/ details.asp?issueno=10992\&article=506263\#.YIiGL5Azbi c (April, 2020).

Ammonnew (2014). Online: https://www.ammonnews.net/article/212250 (April, 2020).

Bank, T. W. (2019). World Development Indicators I The World Bank. http://wdi.worldbank.org/tables

Dhakal, R. C. (2014). Classification of Informal sector activities in Chitwan District. The Academia Vol. 2 No. 1, pp. 106- 120.

DoS. (2020). Unemployment rate during the first quarter of 2020. http://dos.gov.jo/dos_home_a/main/archive/unemp/2020/Emp_Q1_2020.pdf

Husseini, J. Al. (2016). Challenges Facing Jordan's Labour Market. In Atlas of Jordan (pp. 354368). Presses de l'Ifpo. https:// doi.org/10.4000/books.ifpo.5039

International Labour Organization. (1993). Resolution concerning statistics of employment in the 
informal sector. January, 300. https://www.ilo.org/wcmsp5/groups/public/--dgreports/---stat/documents/normativeinstrument/wcms_087484.pdf

Khalil, A. A. (2019). Fighting rugs is definitely a losing battle. http:/ / www.zamancom.com/?p=2960

Kjell \& Borges. (2019). Amman, one of the fastest grown cities in the world, is moving towards sustainable city planning | Nordregio. http://nordregio.org/amman-one-of-the-fastestgrown-cities-in-the-world-is-moving-towards-sustainable-city-planning/

Great Amman Municipality. (2009). System for monitoring and organizing street vendors, rugs, umbrellas and kiosks within the boundaries of the municipal areas No. 81 for the year 2009. https:// portal.jordan.gov.jo/

Saunders, S., \& Loots, E. (2015). Measuring the informal economy in South Africa. South African Journal of Economic and Management Sciences, 8(1), 92-101. https:// doi.org/10.4102/sajems.v8i1.1286

Schneider, F. (1986). Estimating the Size of the Danish Shadow Economy using the Currency Demand Approach: An Attempt. The Scandinavian Journal of Economics, 88(4), 643. https://doi.org/10.2307/3440435

Sharma, S. (2016). Hawking Space and National Policy on Urban Street Hawkers: A Study of NDMC, Delhi. Procedia Technology, 24, 1734-1741. https:// doi.org/10.1016/j.protcy.2016.05.207

Smith, P. (1994). Assessing the Size of the Underground Economy: The Statistics Canada Perspective - ARCHIVED. Canadian Economic Observer, 3(11-010), 16-33. https://www150.statcan.gc.ca/n1/en/catalogue/13-604-M1994028

Potter, R. B., Darmame, K., Barham, N., and Nortcliff, S. (2009), "Ever-growing Amman", Jordan: Urban expansion, social polarisation and contemporary urban planning issues. Habitat International, 33(1), 81- 92

Widjajanti, R. (2016). The space utilization by street vendors based on the location characteristics in the education area of Tembalang, Semarang. Procedia-Social and Behavioral Sciences, 227, 186-193. 